\title{
ANTECEDENTS AND CONSEQUENCES OF MOTIVATION, SELF-ESTEEM, ACADEMIC CULTURE, SOCIAL INTELLIGENCE, AND LEARNING BEHAVIOR TO THE LEVEL OF UNDERSTANDING OF ACCOUNTING
}

\author{
Sarah Yuliarini, Desi Monarista Gultom \\ Faculty of Economics and Business \\ Universitas Wijaya Kusuma Surabaya
}

\begin{abstract}
This study aims to explain the factors that can influence the students at the University of Wijaya Kusuma Surabaya in understanding accounting as a form of knowledge. Determination of samples uses the purposive sampling method and resulted in 60 respondents. This study collected samples of seventh semester accounting students who are submitting their undergraduate final assignments, and the sample have fulfilled the required accounting courses. Not all of the variables analyzed influence the level of understanding of accounting. The variable of Social Intelligence, the variable of Learning Behavior, and the variable of Academic Culture are proven to have influence on students' understanding of accounting. The variable of Motivation and Self-Esteem have no influence on the students' level of understanding on accounting.
\end{abstract}

Keywords: social intelligence; learning behavior; motivation; self-esteem; academic culture and understanding level of accounting

\section{INTRODUCTION}

In the initial stage, we made an observation to find out how many students at Wijaya Kusuma Surabaya University who were taking a thesis actually understand basic accounting. The initial observation with a survey approach of 28 semester VII students showed that $32.14 \%$ or around 9 students understood basic accounting while 19 other students did not understand basic accounting. To produce qualified undergraduate accounting graduates, the tertiary institution

\footnotetext{
*Corresponding Author.

e-mail: sarahyuliarini@uwks.ac.id
} 
must know the factors that influence a student in understanding the lessons they received. Most educational programs are only centered on intellectual intelligence, even though it must be balanced with the intelligence of his personality. Many examples around us have proven that people who have a high degree of brain intelligence are not necessarily successful in the world of work.

Accounting understanding is influenced by various factors and the first is motivation. It also affects the level of understanding of accounting. Everything we do in both the world of education and work, surely have been driven by motivation. Motivation can also be interpreted as a power in carrying out something or work. If our motivation when entering college in an accounting study program is just to look for fun without thinking about the future, or if there is no other motivation, then in the middle of the course the students' lectures will be hampered and they will have difficulty understanding accounting itself. Therefore, motivation is very influential in order for every student to go further in the world of education.

The second factor is esteem. Esteem is an important asset in order to understand accounting because it is related to the motivation that supports or facilitates the ability and potential and how to use accounting knowledge. According to Laguna (2013), self-esteem in one's own abilities is the first step towards success. Of course, self-esteem in the scope of the teaching and learning process is very important, as without high self-esteem it is impossible to have high understanding.

The third factor is academic culture. Academic culture is important in understanding accounting because academic culture in learning is not only attending lectures by listening to lecturers delivering their lectures but also learning ways that teach us to have more skills for use in the public or the community.

The fourth factor is social intelligence. In understanding accounting, the existence of social intelligence influences the level of understanding in students. A student who has good social intelligence will be able to get along and interact well with the community. Sumardi (2007: 120) defined social intelligence as a person's ability to communicate, build relationships and work together, accept differences, assume responsibility, respect other people's rights, and the ability to 
Sarah Y., Desi M.G. / Antecedents and Consequences of Motivation, Self-Esteem, Academic Culture, Social Intelligence, and Learning Behavior to the Level of Understanding of Accounting

benefit others. Social intelligence means one's ability to make surrounding people feel comfortable and relaxed with one's existence.

The fifth factor is learning behavior. Learning behavior is important in understanding accounting because learning behavior is related to the learning styles of individual students that begin from understanding the meaning of lectures, learning experiences or values, independence in learning, the concept of having books, and language skills. Learning behavior is a students' habit that occurs repeatedly and determine whether or not the results are obtained by students. This is in accordance with the opinion of Kosasih, et al (2013), who stated that children's learning success in school is greatly influenced by the way children learn. According to Soewardjono (2009), good learning behavior consists of: (1) The habit of taking lessons, (2) The habit of reading books, (3) The habit of visiting the library, and (4) The habit of facing exams. Good learning behavior can be actualized if students are aware of their responsibilities, so they can divide their time well between learning and activities outside of learning.

The level of understanding of accounting is the extent to which the ability to understand accounting as both as a tool of knowledge and as a process or practice. The level of understanding of a student in understanding a subject is not only shown from the values gotten in the course but also the understanding and mastery of related concepts. Students can be said to have mastered or understood accounting if the accounting knowledge they have acquired can be applied in social life or can be practiced in the world of work (Budhiyanto and Nugroho, 2004; Hanum, 2011).

Accounting understanding is the main benchmark in order to find out the success of learning in one's accounting field. However, the sign of a student understanding financial accounting courses is not only shown from the values obtained in the course but also in the understanding and mastery of related concepts (Praptiningsih (2009) in Evytasari (2010). So, this is what underlies the desire of the author to conduct a research with the title "Antecedents and Consequences of Motivation, Self-Esteem, Academic Culture, Social Intelligence, and Learning Behavior to the Level of Understanding of Accounting”. 


\section{LITERATURE REVIEW}

\section{a. Effects of Motivation on Understanding of Accounting}

Motivation is the drive to reach the goal. With our motivation as students in undergoing the lecture process, of course we can get through accounting learning which is increasingly difficult to understand each semester. It is different with students who do not have motivation, as they do not have any direction to go to.

H1: Motivation affects the level of understanding of accounting

\section{b. Effect of Self-Esteem to the Understanding of Accounting}

Self-esteem in one's own abilities has a positive value. With self-esteem, whether we lack mastery in lecture material or understanding, with self-esteem we are more appreciative of our own abilities and have no need to blame ourselves. Self-esteem or self-confidence in one's own abilities will help improve accounting understanding. This means that believing one's own abilities, optimistism, objectivity, and responsibility as part of self-esteem can help improve accounting understanding.

$\mathrm{H} 2$ : Esteem affects the level of understanding of accounting

\section{c. Effects of Academic Culture on Accounting Understanding Levels}

Culture can be defined as programming of the mind that distinguishes members of one human group from another (Hofstede, 2011). Each human group has its own norm which consists of general characteristics. Students who have better and more modern learning culture will be better at understanding accounting subjects compared to students who have a learning culture that is lagging behind.

H3: Academic culture influences the level of understanding of accounting

d. The Effect of Social Intelligence on the Level of Accounting Understanding

People with high social intelligence will not have difficulty when starting an interaction with a person or a group, both small and large groups. He can utilize 
and use the ability of the brain and understanding of body language to "read" his interlocutors.

H4: Social intelligence influences the level of understanding of accounting

\section{e. Effect of Learning Behavior to the Understanding of Accounting}

Suwardjono (2004) stated that aspects of learning in Higher Education include courses, learning experiences or values, and independence in learning. In all these aspects, the measurement of accounting understanding is important to know the extent of a student's accounting understanding.

H5: Learning behavior affects the level of understanding of accounting

\section{f. Definition of Variable Operations}

1. Motivation

Use our deepest desires to move and guide us toward our goals. According to Goleman (2003), the elements of motivation are as follows:

- The drive for achievement is the drive to become better to meet success standards.

- Commitment that is adjusting to the target group.

- Initiative, namely the readiness to take advantage of opportunities.

2. Self-Esteem

According to Fereira (in Agustian, 2001), a consultant from Deloitte and Touche Consulting, the characteristics of individuals who have a sense of selfconfidence are:

- Belief in own abilities.

- Does not show a desire to be praised by many people.

- Dare to accept and face the rejection of others and dare to be yourself.

3. Academic Culture

According to Kaelan, there are a number of characteristics of the scientific community that must be developed and are also the culture of an academic society, which consist of:

- Critical Attitude, of which every student must develop an attitude of curiosity about everything to further endeavor to solve problems in a study or learning process. 
- Creativity, namely students develop an attitude of initiative, trying to find something new and useful for their surroundings.

- Objectivity, namely the activities carried out must be based on a scientific truth, not because of power, money, or personal ambition.

4. Social Intelligence

This variable uses 2 indicators of social intelligence, namely social awareness and social facilities according to research by (Dwijayanti, 2009).

5. Learning Behavior

Learning behavior is often called learning habits, which is a dimension of learning that individuals perform repeatedly that it becomes automatic and spontaneous. Measuring instruments used to measure learning behavior variables uses a questionnaire adopted from Indah and Suryaningsum (2003), which was developed into 4 dimensions, namely:

- The habit of attending lessons

- The instrument used in the habit of following the lesson in the form of a questionnaire distributed to respondents which includes questions on how much attention and activeness a student has in the learning process.

- The habit of reading books

- The instrument used in the habit of reading books is in the form of a questionnaire distributed to respondents which includes questions on how many books were read and what types of readings students read every day.

- Library visit

- The instrument used in the library visit was a questionnaire distributed to respondents which included questions on how often students visited the library each week.

- The habit of taking exams

- The instrument used in the habit of taking exams is in the form of a questionnaire distributed to respondents which includes questions on how students prepare for the exam.

Based on the definition and elements of each of the independent variables above, a research instrument in the form of a questionnaire was used. The 
dependent variable is the level of understanding of accounting, namely how much a student understands what has been learned, which in this context refers to the accounting courses taken. The variable level of accounting understanding is measured using a questionnaire adopted from Dwijayanti (2009), which is adjusted to the sample being studied by researchers.

\section{RESEARCH METHODS}

\subsection{Population and Sampling}

The sample of respondents is taken according to the length of study during semester VII. Questionnaires were distributed by visiting the prospective respondents one by one, checking whether the candidate had fulfilled the requirements as a prospective respondent, then asking about the willingness to fill out the questionnaire. This procedure is important because the researcher wants to keep the questionnaire filled only by respondents who have met the requirements and are willing to fill it sincerely.

Respondents taken are VII semester students because in the top semester or the average semester in which students are doing their thesis it is natural for them to truly understand accounting both in theory and practice, but not all VII semester students are still active as students, as there are several who was no longer active as a student at a private university in Surabaya. Basically, first and second semester students are the first to know about accounting, therefore the VII semester students should still understand their accounting. Actually not only in semester VII, but semester III, IV, V, and VI students must also have pertinent knowledge of accountancy, as what have been observed through the survey approach, actually the higher the semester level, students put aside more what they had before and this causes students to forget basic accounting. Therefore, a sample of accounting students in semester VII was taken, which from the results of the initial observation were still many semester VII students or those who were taking thesis who are still weak in terms of accounting understanding, which have become an obstacle for these students. 


\section{DISCUSSION}

Based on the results of the F-test above, it can be seen that the variables of motivation, self-esteem, academic culture, social intelligence, and learning behavior together affected the level of understanding of accounting. This is evidenced by the sig value of $0.006<0.05$.

Table 1 - F Test Result

\begin{tabular}{c}
\hline F test (Simultant)Sig. \\
\hline 0,006 \\
\hline
\end{tabular}

Based on the results of the t-test above, it can be seen that the variable of academic culture has a significance of 0.001 , social intelligence has a significance of 0.003 , and learning behavior has a significance of 0.048 . These affect the level of accounting understanding as evidenced by the value of $<0.05$.

Table 2 -T Test (Partial)

\begin{tabular}{ll}
\hline Independent Variables & Sig. \\
\hline Motivation & 0,943 \\
\hline Self-Esteem & 0,978 \\
\hline Academic cultures & 0,001 \\
\hline Social Intelligent & 0,003 \\
\hline Learning Behavior & 0,048 \\
\hline
\end{tabular}

The results of this study are in line with the study of Aiga and Adi (2015) which stated that academic culture influences the level of understanding of accounting. Students who have a better and modern learning culture will be better in understanding accounting subjects compared to students who have a learning culture that is lagging behind. In the researcher's opinion, the cultural differences in learning it is very interesting, also regarding how the way the lecturer teaches attracts the attention of his students, it is very easy for us as students to understand the lecture material. Likewise for students, if they have 
a different learning culture as they are accustomed to adding the literature to guide learning and culture, the intended literature is the presence of facilities and infrastructure needed as a support for learning accounting.

Things like that will be more beneficial for us as students to facilitate our understanding of the lecture material. For social intelligence variables, the results of this study supported the research of Pintoa, Fariab, and Maria (2013) which stated that social intelligence influences the level of understanding of accounting. However, why are there more and more associations but this do not increase accounting understanding in students? In the researcher's opinion, the quality of relationship they held and the extent of the discussion in each meeting conducted by students in the community is influential. Problems like this often occur among students as they should focus more on their goals to get along with lectures and take advantage of the time and relationships available so that all is not in vain, since they can help one another in the community, or maybe exchange ideas or share knowledge or insight.

For learning behavior variables, the results of this study are consistent with research conducted by Hariyoga and Supriyanto (2011) which stated that learning behavior influences the level of accounting understanding. But why does learning behavior increases but understanding in accounting decreases? What needs to be investigated on issues like this is how students study on campus with their peers, whether or not they discuss accounting materials or do they discuss it outside of lecture material or do they just gather and talk more than study. The existence of learning without an understanding of accounting among students is known as the overnight speeding system that is still carried out by students and the lack of senior tutorials on juniors caused the understanding of students in accounting to decrease. Herein, institution need to provide learning system not only engage with lecturer but another senior students also to deepened transfer knowledge.

\section{CONCLUSION}

Based on the F-test it can be seen that motivation, self-esteem, academic culture, social intelligence, and learning behavior together affect the level of 
understanding of accounting. Based on the t-test it can be seen that only academic culture, social intelligence, and learning behavior affect the level of understanding of accounting. While motivation and self-esteem esteem only partially affect the level of understanding of accounting. As for the researcher's advice:

- Expand the population so that the research population is not only taken from one tertiary institution in Surabaya.

- Add other independent variables that have the possibility to influence understanding of accounting in addition to the variables used in this study.

- Extend the research, as it might be better if the research is carried out on different objects and research subjects.

- A study will add new findings by each researcher. The findings in this study are strengths assessed by accounting students at Wijaya Kusuma Surabaya University in accounting education that must be supported by the institution. In this case, this institution should provide a place for every accounting student to be able to dialogue or exchange opinions in the department. With this forum, students do not need to struggle to understand existing accounting materials. Not only students who are still relatively active on campus, but seniors can also join to share their experience while studying accounting in the workforce.

\section{ACKNOWLEDGEMENTS}

The authors thanked God Almighty, because of His grace the authors were able to complete this research and the authors received help and support from various parties related to collect data. Therefore, the author would like to thank Mr. Bambang Yunarko, S.H., M.H., Deputy Chancellor for Student Affairs, Wijaya Kusuma University, Surabaya and Ms. Lilik Mardiana, S.E., M.Ak., Ak., C.A., Chair of the Accounting Study Program at the Faculty of Economics and Business, Wijaya Kusuma University, Surabaya. 
Sarah Y., Desi M.G. / Antecedents and Consequences of Motivation, Self-Esteem, Academic Culture, Social Intelligence, and Learning Behavior to the Level of Understanding of Accounting

\section{REFERENCES}

Agustian, A.G. 2001. Rahasia Sukses Membangun Kecerdasan Emosi dan Spiritual. Jakarta: Agra Publishing.

Aiga, K. and Adi, S.W. 2015. The Influence of Emotional Intelligence, Self Esteem, Learning Behavior, and Academic Culture Against the Level of Accounting Understanding: Empirical Studies in Accounting Study Program Students (Pengaruh Kecerdasan Emosional, Kepercayaan Diri, Perilaku Belajar, dan Budaya Akademik Terhadap Tingkat Pemahaman Akuntansi (Studi Empiris pada Mahasiswa Program Studi Akuntansi). Thesis. Universitas Muhammadiyah Surakarta.

Budhiyanto, S.J. and Nugroho, I.P. 2004. The Effect of Emotional Intelligence on the Level of Accounting Understanding (Pengaruh Kecerdasan Emosional terhadap Tingkat Pemahaman Akuntansi). Jurnal Ekonomi Bisnis, 10(2), pp. 260-281.

Budhiyanto, S.J. and Nugroho, I.P. 2004. Pengaruh Kecerdasan Emosional terhadap Tingkat Pemahaman Akuntansi. Jurnal Ekonomi Bisnis, 10(2), pp. 260-281.

Dwijayanti, A.P. 2009. Pengaruh Kecerdasan Emosional, Kecerdasan Intelektual, Kecerdasan Spiritual, dan Kecerdasan Sosial Terhadap Pemahaman Akuntansi. Skripsi. Fakultas Ekonomi, Universitas Pembangunan Nasional "Veteran": Jakarta.

Goleman, D. 2013. Emotional Intelligence. Retrieved from http://danielgoleman. info/topics/emotional-intelligence/Accessed: 12. June 2013.

Hanum, F. 2011. Sosiologi Pendidikan. Yogyakarta: Kanwa Publisher.

Hariyoga, S. dan Suprianto, E. 2011. Proceeding from Simposium Nasional Akuntansi XIV, 21-22 Juli, Aceh. The Effect of Emotional Intelligence, Learning Behavior, and Culture on the Level of Accounting Understanding with Self Esteem as a Moderating Variable (Pengaruh Kecerdasan Emosional, Perilaku Belajar, dan Budaya terhadap Tingkat Pemahaman Akuntansi dengan Kepercayaan Diri sebagai Variabel Pemoderas).

Hofstede, G. 2011. Dimensionalizing Cultures: The Hofstede Model in Context. Online Readings in Psychology and Culture, 2(1). https://doi.org/10.9707/ 2307-0919.1014. 
Indah, E.T. and Suryaningsum, S. 2003. Proceeding from Simposium Nasional Akuntansi VI: Surabaya. Influence of Emotional Intelligence on the Understanding of Accounting (Pengaruh Kecerdasan Emosional Terhadap Tingkat Pemahaman Akuntansi).

Kosasih. 2014. Strategi Belajar dan Pembelajaran Implementasi Kurikulum 2013. Bandung: Penerbit Yrama Widya.

Laguna, M. 2013. Self Efficacy, Self Esteem, and Entrepreneurship among the Unemployed. Journal of Applied Social Psycology, 43(2),pp.253-262.

Pintoa, J.C., Fariab, L. dan Maria C.T. 2013. Social Intelligence in Portuguese Students: Differences According to the School Grade, Procedia-Social and Behavioral Sciences, 116 (2014), pp.56-60.

Sumardi. 2007. Pasword Menuju Sukses Rahasia Membangun Sukses Individu, Lembaga, dan Perusahaan. Jakarta: Penerbit Erlangga. 